\title{
Non-volant mammals from Núcleo Santa Virgínia, Serra do Mar State Park, São Paulo, Brazil
}

\author{
Fabiana Rocha-Mendes ${ }^{1,2,3}$, Carolina Lima Neves ${ }^{2}$, Rodrigo de Almeida Nobre ${ }^{2}$, Renato Matos Marques ${ }^{2}$, \\ Gledson Vigiano Bianconi ${ }^{1}$ \& Mauro Galetti ${ }^{2}$ \\ ${ }^{I}$ Instituto Neotropical, Pesquisa e Conservação, Curitiba, PR, Brazil. \\ ${ }^{2}$ Laboratório de Biologia da Conservação, Departamento de Ecologia, Instituto de Biociências, Universidade \\ Estadual Paulista, Rio Claro, SP, Brazil. \\ ${ }^{3}$ Corresponding author: Fabiana Rocha-Mendes, e-mail: frm@institutoneotropical.org
}

ROCHA-MENDES, F., NEVES, C.L., NOBRE, R.A., MARQUES, R.M., BIANCONI, G.V., GALETTI, M. Non-volant mammals from Núcleo Santa Virgínia, Serra do Mar State Park, São Paulo, Brazil. Biota Neotropica. 15(1): e20140008. http://dx.doi.org/10.1590/1676-06032014000814

\begin{abstract}
This study presents data on the composition and species richness of non-flying mammals in the northern part of the Parque Estadual da Serra do Mar, called Núcleo Santa Virgínia (NSV - around 17000 hectares of Atlantic Forest), São Paulo state, southeastern Brazil. The species list was based on $c a$. $660 \mathrm{~km}$ of line-transects, 25512 hours of cameras traps, 7740 trap.nights for small mammals, and 394 track-station.days, as well as occasional records and registers from local people (period 2002 to 2009). Based on these complementary methods, a total of 58 species were recorded from the 85-104 possible. Eighteen taxa are listed in the Brazilian endangered species list, 29 in the state list. The high species richness of non-volant mammals and the presence of threatened species show the importance of NSV for the conservation of Atlantic Forest mammals.
\end{abstract}

Keywords: Atlantic forest, inventory, Mammalia, sampling methods, species richness.

ROCHA-MENDES, F., NEVES, C.L., NOBRE, R.A., MARQUES, R.M., BIANCONI, G.V., GALETTI, M. Mamíferos não voadores do Núcleo Santa Virgínia, Parque Estadual da Serra do Mar, São Paulo, Brazil. Biota Neotropica. 15(1): e20140008. http://dx.doi.org/10.1590/1676-06032014000814

Resumo: Este estudo apresenta dados de composição e riqueza de espécies de mamíferos não voadores da porção norte do Parque Estadual da Serra do Mar, que corresponde à região do núcleo Santa Virgínia (NSV - cerca de 17.000 hectares de Floresta Atlântica), estado de São Paulo, sudeste do Brasil. A listagem de espécies foi elaborada durante o período de 2002 a 2009, por meio de ca. $660 \mathrm{~km} \mathrm{de}$ transecções lineares, 25.512 horas de armadilha fotográfica, 394 armadilhas-de-pegada.dia, registros ocasionais e relatos de moradores da região (entrevistas) para mamíferos de médio e grande porte, e 7.740 armadilhas.noite para pequenos mamíferos. Foram registradas 58 espécies de 85-104 de possível ocorrência dada suas potenciais distribuições. Dezoito espécies fazem parte da lista nacional da fauna ameaçada de extinção e 29 da lista estadual. A elevada riqueza de mamíferos não voadores com a presença de várias espécies ameaçadas, indica a importância do NSV para conservação da mastofauna regional.

Palavras-chave: Floresta Atlântica, inventário, Mammalia, métodos de amostragem, riqueza de espécies.

\section{Introduction}

The Atlantic Forest, one of the most threatened biomes on the planet, contains 298 species of mammals, 90 of which are endemic (Paglia et al. 2012) and 14\% threatened under extinction (Chiarello et al. 2008). With approximately $60 \%$ of the Brazilian population living in these areas (Pinto et al. 2006), the Atlantic Forest remains under pressure due to urbanization, increasing road network, construction of pipelines, uncontrolled growth of ecotourism (SMA 1999, MMA 2002), hunting and extraction of plant resources (Galetti \& Chivers 1995, Dean 1996, Galetti \& Fernandez 1998, Cullen et al. 2000). As a consequence, currently less than $11 \%(16,377,472$ ha) of its original vegetation remains, and of these, only $13.8 \%$ are legally protected (Ribeiro et al. 2009).

Although threatened and with an urgent need for scientific surveys, biodiversity in few localities of this biome have been investigated, and most often, few groups were targeted for study. In the case of mammals, this scenario is further complicated. Rare are the times in which the group is inventoried as a whole (e.g. Voss \& Emmons, 1996), studies with partial sampling being more common. These "partial" studies lacks some methods and/or last just a short time. Mammal surveys tend to adopt the following division, based on 
animals' habits and different sampling protocols: small terrestrial mammals (e.g. Barros-Battesti et al. 2000, Pardini \& Umetsu 2006, Pinto et al. 2009), Bats (e.g. Bianconi et al. 2004, Faria et al. 2006, Luz et al. 2011) and medium and large bodied mammals (e.g. Negrão \& Valladares-Pádua 2006, Abreu \& Köhler 2009). Exceptions being studies, such as Geise et al. (2004), Cunha \& Rajão (2007) and Passamani et al. (2005) that included all non-flying mammals, or even Paglia et al. (2005) and Modesto et al. (2008) that additionally included bats.

The largest set of Atlantic Forest remnants is located in the Serra do Mar, mainly in the state of São Paulo and represents approximately $7 \%$ of what remains of the biome (Ribeiro et al. 2009). The Serra do Mar State Park ("Parque Estadual da Serra do Mar" - PESM ) protects an area of 315,000 ha in this region, situated in a highly populated area of São Paulo (ca. 14 million) (Instituto Florestal 2006). Due to its size, the park is managed through eight regional administrative centers that are in different situations with regard to regularization, environmental pressures, conservation status and fiscalization (Instituto Florestal 2006).

Located in the northern portion of PESM the Núcleo Santa Virginia (NSV) is recognized for its high biological diversity, being an active site for important faunal and floristic studies in the state of São Paulo (e.g., Galetti et al. 2009, Rocha-Mendes 2010, Martins 2011, Silva \& Tozzi 2013). Among terrestrial vertebrates, some groups that have been locally assessed include birds (Goerck 1999), serpents (Hartmann et al. 2009) and fish (Gomiero \& Braga 2006). For mammals, the species list available comes from the Management Plan of the park (Instituto Florestal 2006) and Wang (2002), who described the diets of three spotted cats and listed their preys. With the aim of expanding the knowledge of mammals in this important conservation area, the PESM, and in particular the NSV, this paper presents the results obtained through a combination of field sampling methods applied during the period of 2002-2009 to survey non-flying mammals.

\section{Material and methods}

\section{Study area}

Núcleo Santa Virginia (NSV - $23^{\circ} 17^{\prime}$ to $23^{\circ} 24^{\prime} \mathrm{S}$ and $45^{\circ} 03^{\prime}$ to $40^{\circ} 11^{\prime} \mathrm{W}$ ) is an administrative division of the Serra do Mar State Park. NSV covers approximately 17,000 ha, and is located within the municipalities of Cunha, Natividade da Serra, São Luis do Paraitinga and Ubatuba in the State of São Paulo (Figure 1). NSV is situated on a narrow strip of the Atlantic plateau between the coast and the Paraiba valley, forming the Atlantic Plateau Unit ("Unidade Planalto Atlântico") - of the Upper Paraíba Basin ("Bacia Superior do Paraíba"). The local climate is "coastal humid characteristic of tropical coasts exposed to the Atlantic" with an annual average rainfall of 2,200 $\mathrm{mm}$ and seasonal rainfall differences, with the austral autumn and winter periods considered driest. The average temperature ranges from $18{ }^{\circ} \mathrm{C}$ to $22{ }^{\circ} \mathrm{C}$ (Instituto Florestal 2006).

Vegetation cover consists of $60 \%$ dense rainforests and pristine/little changed montane forests, with the remainder a mixture of disturbed areas and plantations of Pinus spp. and Eucalyptus saligna (Tabarelli et al. 1994, Instituto Florestal 2006), the relief is very steep with embedded valleys and straight strands, and the average altitude is 860 meters to 1500 meters (Instituto Florestal 2006). Hunting pressure within NSV ranges from almost nonexistent to moderate (Marques 2004) and it is considered a priority area for PESM biodiversity conservation, due to the floral and faunal importance of the region, with species restricted to the plateau and highly diverse primary vegetation (Instituto Florestal 2006). Most of the mammal sampling effort was concentrated around two research bases: Itamambuca (headquarters - 45 5'16”'W/2319'29'S) - located in the northern portion, bordering Núcleo Cunha and Vargem Grande (headquarters - 45 $14^{\prime} 39^{\prime \prime} \mathrm{W} / 23^{\circ} 26^{\prime} 16^{\prime \prime} \mathrm{S}$ ) - located in the central portion, bordering Núcleo Picinguaba (Figure 1).

\section{Data collection}

Mammal species were recorded through a combination of standardized methods, namely: diurnal and nocturnal line transect census, camera trapping, track-stations, live-traps (Sherman traps of three different sizes $[23 \times 7.5 \times 8.5 \mathrm{~cm}$, $30 \times 7.5 \times 9.5 \mathrm{~cm}$, and $37.5 \times 10 \times 12 \mathrm{~cm}$ ], and Tomahawk traps [45 x $16 \times 16 \mathrm{~cm}]$ ), pitfalls, as well as occasional records and information from third parties.

Sampling of small non-flying mammals - here marsupials and cricetidae and echimyids rodents - was performed with equal effort in both research bases in bimonthly sessions of five capture nights, from September 2008 to September 2009. One hundred and eighty live traps were distributed equally in six sample plots of 0.6 ha $(60 \times 100 \mathrm{~m})$, three at each base. Each plot consisted of 24 sample locations ( $20 \mathrm{~m}$ equidistant), which randomly received a Sherman trap, and six also received a Tomahawk, totaling 30 traps per plot, always located on the ground. Additionally, twelve lines of pitfall traps were installed, six in each base. Each line consisted of four $60 \mathrm{~L}$ plastic buckets separated by $10 \mathrm{~m}$ and joined by a plastic screen (approximately $50 \mathrm{~cm}$ tall), the lines were paired, equally spaced 30 meters. At the same base, both live trap plots and pitfall line pairs were separated by at least $100 \mathrm{~m}$ from the closest plot or line pair.

The live traps, as well as pitfalls were baited with a mix of mashed banana, peanut butter, bacon and ground cornmeal. The marsupials and rodents caught were identified and marked with numbered tags (Ear tags, National Band and Tag Co., Newport, Kentucky, USA) and then released (following guidelines of the American Society of Mammalogists - ASM, Sikes et al. 2011). Due to the difficulty of identifying species using only external characters, some specimens were retained for morphological, cytogenetic and molecular analysis (with specialists' help), and comparison with reference collections (IBAMA license No. 14428-2). These specimens were submitted as references to the Museu de Zoologia da Universidade de São Paulo (MZUSP), Museu Nacional (MN) and Museu da Universidade Federal do Espírito Santo (UFES). Specimens that had not been deposited yet in these scientific collections are denoted by the initials of the collector: Carolina Lima Neves (CLN) (more information Di-Nizo et al. 2014).

The sampling success of terrestrial small mammals was assessed using species accumulation curves and rarefaction curve (Jackknife 1), both related to the sampling effort in number of traps per night - EstimateS Version 8.2.0 (Copyright R. K. Colwell: http://viceroy.eeb.uconn.edu/estimates) program (Colwell 2009).

The records of other terrestrial mammals took place during two sampling periods, from 2002 to 2005 and then from 2007 to 2009. The methods used were line transects, camera traps and track-stations, along pre-existing trails within NSV (trails: Rio Grande, Rio do Veado, Pau de Bala, Santa Virgínia-Cunha), 

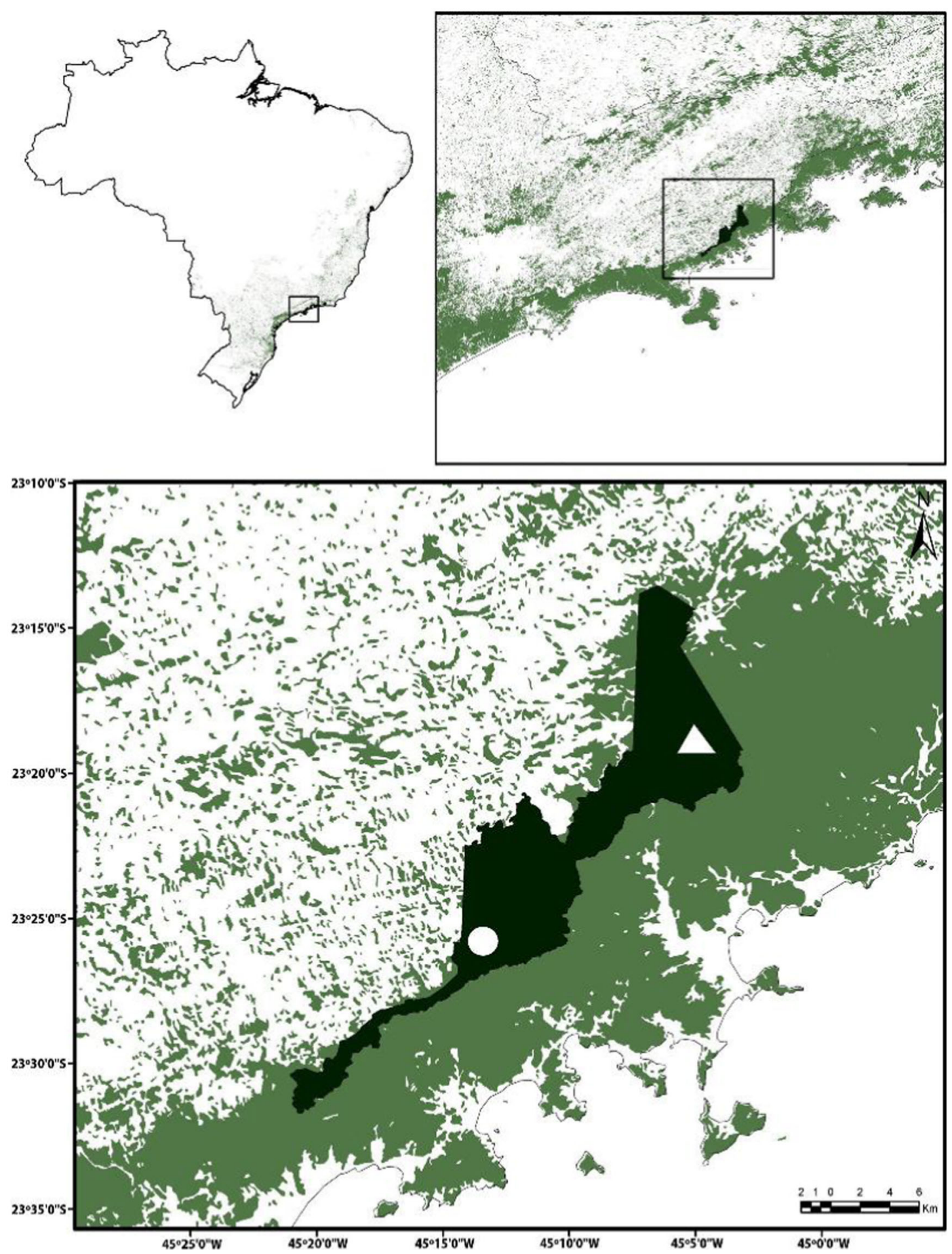

Figure 1. Location of Núcleo Santa Virgínia, Serra do Mar State Park - east São Paulo State, in the context of Brazil, showing remnants of Atlantic Forest (source: SOS Mata Atlântica 2010). In detail the study sites: Vargem Grande base = circle, Itamambuca base $=$ triangle.

predominantly close to the research bases of Itamambuca and Vargem Grande, in native vegetation area. Transects were walked (average speed of $1 \mathrm{~km} / \mathrm{h}$ ) throughout the day and timings varied with climatic conditions. The camera traps were placed along the trails and in the forest, where they remained active for seven to 30 consecutive days. Track-stations were used for only three months (August-November 2004) and consisted of sand plots (50 x $50 \mathrm{~cm} \times 3 \mathrm{~cm}$ deep), spaced every $100 \mathrm{~m}$ along four trails, totaling 59 stations. Each of the track-station trails was evaluated for six to eight times during the sample period.

The sampling effort employed at the end of the study using systematic methods can be seen in Table 1, in addition, other records were collected on an occasional basis over the course of field activities as well as through informal conversations with NSV staff and locals. To compile the species list for the area, basic information from the Parks management plan was also 
Table 1. Sampling effort used to survey non-volant mammals in Núcleo SantaVirginia, Serra do Mar State Park - São Paulo.

\begin{tabular}{ll}
\hline Method & Effort \\
\hline Line transect & $659.15 \mathrm{~km}$ \\
Camera traps & $25,512 \mathrm{~h}$ \\
Track-stations & 394 station.days \\
Live trap & 6,300 trap.nights \\
Pitfall & 1,440 bucket.nights \\
\hline
\end{tabular}

considered (Instituto Florestal 2006). The conservation status of the species in state and national levels followed the information available at: Fauna Ameaçada de Extinção no Estado de São Paulo: Vertebrados (2009), MMA \& Fundação Biodiversitas (2008) and Machado et al. (2005).

\section{Results}

A total of 58 species of non-flying mammals were recorded at NSV, of which 50 were captured or observed using standardized techniques (present study), six from reports regarding current or historical presence in the area (Chironectes minimus, Callicebus nigrifrons, Brachyteles arachnoides, Panthera onca, Chrysocyon brachyurus and Speothos venaticus), and two during the implementation of the Management Plan (Monodelphis americana and Akodon cursor) (Table 2). With 20 species Rodentia was the best represented order, followed by Carnivora $(n=9)$ and Didelphimorphia $(\mathrm{n}=9)$ (Table 2). Canis lupus familiaris was the only exotic species recorded in the NSV, however was not included in the final listing.

Among the methods used, interviews and the occasional records provided the greatest number of species, with $29(50 \%$ of the total) and $26(45 \%)$ species, respectively. Approximately $41 \%$ of the species were uniquely identified by a single sampling method and approximately $29 \%$ were recorded using two different methods. Track-stations and line transects did not produce unique records of any mammal, while the data collected using live-traps, pitfalls and interviews resulted in three, seven and six unique records, respectively (Table 2).

Mean cumulative species curve, made on the basis of 20 taxa of small mammals captured, considering the effort of both the live and pitfall traps, showed a tendency towards stabilization, whereas the cumulative curve of species caught showed that only two additional taxa were included in the sample after the first half of the sampling effort $(3,870$ trap.nights) (Figure 2). This richness of small mammals corresponds to $87 \%$ of that predicted using the Jackknife 1 estimator (23 species).

Regarding the conservation status, 14 of the 58 species (i.e., $24 \%$ of the total) are under threat at the state level. Being classified as "Critically Endangered" (CE): Panthera onca, "Endangered" (EN): Leopardus wiedii, Brachyteles arachnoides, and Tayassu pecari and "Vulnerable" (VU): another 10 species (Table 2). Eleven other species are classified as "Near Threatened" (NT) (i.e. there is an indication that they are close to being classified into one of these categories in the near future), while five qualify as "Data Deficient" (DD). According to the national list of threatened species, eight species are classified as VU and one is listed as EN (Brachyteles

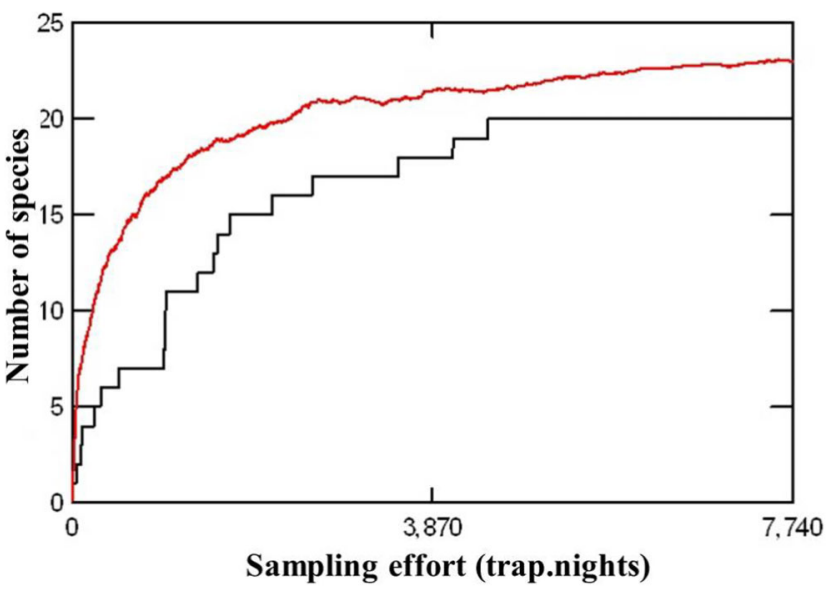

Figure 2. Mean species accumulation curve (red line) and cumulative curve of species captured (in black) of small non-volant mammals in relation to sampling effort.

arachnoides), while four are classified as NT and four as DD (Table 2).

\section{Discussion}

Considering the species of non-flying mammals occurring in Brazil (Paglia et al. 2012), São Paulo (Vivo et al. 2011) and, potentially occurring in the study region (cf. NaturaServe 2014), NSV has $12 \%$ of the recorded species for the country, $45 \%$ of those occurring in the state, and between $55-68 \%$ of species expected for the region (Table 3 ).

In comparing the results of this study with other studies carried out in the Atlantic Forest of southeastern Brazil, NSV has one of the highest species richness of non-flying mammals (Table 2 and 3). In the Parque Estadual do Desengano (RJ $22,400 \mathrm{ha}$ ) a total of 41 taxa were recorded, 17 of them based solely on the reports of others (Modesto et al. 2008). Cunha \& Rajão (2007) recorded 26 species in the Terra Indígena Sapukai (RJ - 2,100 ha), including three exotics (Canis lupus familiaris, Felis catus and Mus musculus), and Passamani et al. (2005) recorded 48 species around the Estação Ecológica Santa Lucia (ES - 440 ha). For the state of São Paulo, De Vivo and Gregorin (2001) reported 58 species for Parque Estadual de Intervales (SP - 48,000 ha) and, more recently, Brocardo et al. (2012) reported 53 species for the Parque Estadual Carlos Botelho (SP - 37,644 ha) - Paranapiacaba forest continuum. Particularly for the PESM, Pinheiro \& Geise (2008) recorded 13 species of small mammals (five marsupials and eight rodents) in núcleo Pinciguaba, located in the lowland forests of the protected area, compared to 24 species ( 9 marsupials and 15 rodents) considered in the present study.

Six new species records have been added to the list of nonflying mammals $(n=69)$ available in the PESM Management Plan - which considers the entire length of the unit (Instituto Florestal 2006). They are, the marsupial Monodelphis sp. and rodents Akodon montensis and Kannabateomys amblyonyx; the armadillo Cabassous tatouay and the canids Chrysocyon brachyurus and Speothos venaticus. Although the last two records came from third-party reports, for the maned wolf the source of information is reliable (J.P. Villani, area manager, reports the capture of an individual within the limits of NSV), and for the bush dog, there is corroborating data available 
Table 2. Mammal species recorded in Núcleo Santa Virginia, Serra do Mar State Park, São Paulo. Taxonomic classification based on Wilson \& Reeder (2005).

\begin{tabular}{|c|c|c|c|c|}
\hline \multirow{2}{*}{ ORDER / FAMILY / Species } & \multirow{2}{*}{ Technical vernacular } & \multirow{2}{*}{ Record type } & \multicolumn{2}{|c|}{ Conservation status } \\
\hline & & & São Paulo & Brazil \\
\hline \multicolumn{5}{|l|}{ DIDELPHIMORPHIA } \\
\hline \multicolumn{5}{|l|}{ DIDELPHIDAE } \\
\hline Chironectes minimus (Zimmermann, 1780) & cuíca-d’água & In & NT & \\
\hline Didelphis aurita (Wied-Neuwied, 1826) & gambá-orelha-preta & $\mathrm{Lt}, \mathrm{Pf}, \mathrm{Ct}, \mathrm{Ro}$ & $\mathrm{LC}$ & \\
\hline Marmosa paraguayana (Tate, 1931) & cuíca & $\mathrm{Lt}$ & $\mathrm{LC}$ & \\
\hline Marmosops incanus (Lund, 1840) & cuíca & $\mathrm{Lt}, \mathrm{Pf}$ & NT & \\
\hline Monodelphis sp. & catita & $\mathrm{Pf}$ & & \\
\hline Monodelphis americana (Müller, 1776) & catita & $\mathrm{B}$ & NT & DD \\
\hline Monodelphis iheringi (Thomas, 1888) & catita & Pf & VU & DD \\
\hline Monodelphis scalops (Thomas, 1888) & catita & $\mathrm{Lt}, \mathrm{Pf}$ & NT & DD \\
\hline Philander frenatus (Olfers, 1818) & cuíca-quatro-olhos & $\mathrm{Lt}, \mathrm{Pf}$ & $\mathrm{LC}$ & \\
\hline
\end{tabular}

\section{CINGULATA}

DASYPODIDAE

Dasypus novemcinctus Linnaeus, 1758

Euphractus sexcinctus (Linnaeus, 1758)

Cabassous tatouay (Desmarest, 1804)

\section{PILOSA}

BRADYPODIDAE

Bradypus variegatus Schinz, 1825

MyrmeCOPHAGIDAE

Tamandua tetradactyla (Linnaeus, 1758)

\section{PRIMATES}

Cebidae

Callithrix aurita (É. Geoffroy, 1812)

Sapajus nigritus (Goldfuss, 1809)

Pithecidae

Callicebus nigrifrons (Spix, 1823)

Atelidae

Alouatta clamitans Cabrera, 1940

Brachyteles arachnoides (É. Geoffroy, 1806)

\section{RODENTIA}

SCIURIDAE

Guerlinguetus ingrami (Thomas, 1901)

CRICETIDAE

Akodon cursor (Winge, 1887)

Akodon montensis (Thomas, 1913)

Blarinomys breviceps (Winge, 1887)

Brucepattersonius soricinus Hershkovitz, 1998

Calomys tener (Winge, 1887)

Drymoreomys albimaculatus Percequillo,

Weksler \& Costa, 2011

Euryoryzomys russatus (Wagner, 1848)

Juliomys pictipes (Osgood, 1933)

Nectomys squamipes (Brants, 1827)

Oligoryzomys nigripes (Olfers, 1818)

Rhipidomys itoan Costa, Geise, Pereira and

Costa, 2011

Sooretamys angouya (Fischer, 1814)

Thaptomys nigrita (Lichtenstein, 1829)

ERETHIZONTIDAE

Coendou spinosus Cuvier, 1823

CAviIDAE

tatu-galinha
tatu peba
tatu-do-rabo-mole

$\begin{array}{lll}\text { bicho-preguiça } & \text { Ro, B } & \text { LC } \\ \text { tamanduá-mirim } & \text { Ct, Ro } & \text { LC }\end{array}$

In, $\mathrm{Ct}, \mathrm{Ro}, \mathrm{B} \quad \mathrm{LC}$

In, Ro LC

Ro DD DD 
Table 2. Continued.

\begin{tabular}{|c|c|c|c|c|}
\hline \multirow{2}{*}{ ORDER / FAMILY / Species } & \multirow{2}{*}{ Technical vernacular } & \multirow{2}{*}{ Record type } & \multicolumn{2}{|c|}{ Conservation status } \\
\hline & & & São Paulo & Brazil \\
\hline Hydrochoerus hydrochaeris (Linnaeus, 1766) & capivara & In, Tl, Ro & $\mathrm{LC}$ & \\
\hline \multicolumn{5}{|l|}{ DASYPROCTIDAE } \\
\hline Dasyprocta iacki Feijó \& Langguth, 2013 & cutia & In, $\mathrm{Tl}, \mathrm{Ct}, \mathrm{Ro}$ & & \\
\hline \multicolumn{5}{|l|}{ CUNICULIDAE } \\
\hline Cuniculus paca (Linnaeus, 1766) & paca & In, Ct, Ro & NT & \\
\hline \multicolumn{5}{|l|}{ ECHIMYIDAE } \\
\hline Kannabateomys amblyonyx (Wagner, 1845) & rato-da-taquara & Ro & DD & \\
\hline Trinomys iheringi (Thomas, 1911) & rato & $\mathrm{Lt}, \mathrm{Pf}$ & LC & \\
\hline \multicolumn{5}{|l|}{ LAGOMORPHA } \\
\hline \multicolumn{5}{|l|}{ LEPORIDAE } \\
\hline Sylvilagus brasiliensis (Linnaeus, 1758) & tapeti & In, Ro, B & $\mathrm{LC}$ & \\
\hline \multicolumn{5}{|l|}{ CARNIVORA } \\
\hline \multicolumn{5}{|l|}{ FELIDAE } \\
\hline Leopardus guttulus (Hensel, 1872) & gato-do-mato & $\mathrm{Ct}, \mathrm{B}$ & VU & VU \\
\hline Leopardus pardalis (Linnaeus, 1758) & jaguaririca & In, $\mathrm{Tl}, \mathrm{Ct}, \mathrm{Ro}, \mathrm{B}$ & VU & VU \\
\hline Leopardus wiedii (Schinz, 1821) & gato-maracajá & $\mathrm{Ct}, \mathrm{B}$ & $\mathrm{EN}$ & VU \\
\hline Panthera onca (Linnaeus, 1758) & onça-pintada & In & $\mathrm{CR}$ & VU \\
\hline Puma concolor (Linnaeus, 1771) & suçuarana & In, Ct, Ro & VU & VU \\
\hline Puma yagouaroundi (É. Geoffroy Saint-Hilaire, 1803) & gato-mourisco & $\mathrm{Ct}$ & $\mathrm{LC}$ & \\
\hline \multicolumn{5}{|l|}{ CANIDAE } \\
\hline Cerdocyon thous (Linnaeus, 1766) & cachorro-do-mato & In, Ct, Ro & $\mathrm{LC}$ & \\
\hline Chrysocyon brachyurus (Illiger, 1815) & lobo-guará & In & VU & VU \\
\hline Speothos venaticus (Lund, 1842) & cachorro-vinagre & In & $\mathrm{DD}$ & VU \\
\hline \multicolumn{5}{|l|}{ Mustelidae } \\
\hline Lontra longicaudis (Olfers, 1818) & lontra & In, Ro & NT & NT \\
\hline Eira barbara (Linnaeus, 1758) & irara & In, $\mathrm{Tl}, \mathrm{Ct}, \mathrm{Ro}$ & $\mathrm{LC}$ & \\
\hline Galictis cuja (Molina, 1782) & furão & In, Ro, B & DD & \\
\hline \multicolumn{5}{|l|}{ PROCYONIDAE } \\
\hline Nasua nasua (Linnaeus, 1766) & quati & In, $\mathrm{Tl}, \mathrm{B}$ & $\mathrm{LC}$ & \\
\hline Procyon cancrivorous (G.[Baron] Cuvier, 1798) & mão-pelada & In, $\mathrm{Ct}, \mathrm{Ro}$ & $\mathrm{LC}$ & \\
\hline
\end{tabular}

\section{PERISSODACTYLA}

TAPIRIDAE

Tapirus terrestris (Linnaeus, 1758)

anta

In, Ct, Ts, Ro

VU

ARTIODACTYLA

TAYASSUIDAE

Pecari tajacu (Linnaeus, 1758)

Tayassu pecari (Link, 1795)

CERvidae

Mazama americana (Erxleben, 1777)

$\begin{array}{lll}\text { cateto } & \text { In, Ct, Tl, Ro } & \text { NT } \\ \text { queixada } & \text { In, Ct, Tl, Ro } & \text { EN } \\ & \text { In, Ro } & \text { VU } \\ \text { veado } & \text { In }\end{array}$

Type of record = VLT - Visual during line transects, Ct - camera traps, Ts - track-station, Lt - live trap (Sherman or Tomahawk), Pf - pitfall, Ro occasional record, In - Interviews, B - bibliographic data (Wang 2002, Instituto Florestal 2006). Conservation Status (species classification category IUCN 2001)/Level of Threat following Decreto N 53.494, (2 October 2008), Fauna Ameaçada de Extinção no Estado de São Paulo: Vertebrados (2009), MMA \& Fundação Biodiversitas (2008) and Machado et al. (2005): NT (Near threatened); LC (Least concern); DD (Data deficient); VU (Vulnerable); EN (endangered); CR (Critically endangered).

(Emmons \& Feer 1997, Eisenberg \& Redford 1999, Cheida et al. 2011) including the study region (lato sensu) within its range. Exclusive records of small mammals from Wang (2002) were not used, because it is not a specific work with the group, which has so many identification intrinsic problems.

For other taxa that were only recorded through interviews, evidences of their current or historical presence in the area are strong and persuasive. Callicebus nigrifrons, for example, occurs in dense mountain rain forest in PESM (Cunha/
Indaiá), a vegetation formation also present in the NSV (Instituto Florestal 2006). Brachyteles arachnoides was recorded in the vicinity, specifically in Cunha (Marques 2004), which is part of the same continuous forest. And, Panthera onca was recently confirmed by genetic analysis of scats carried out by the Departamento de Genética e Evolução - Universidade Federal de São Carlos (P.M. Galetti Jr. pers. com). Finally, Chironectes minimus, the only small species to be recorded only through the reports of others, in addition to being easily 
Table 3. Representation of mammals occurring in Núcleo Santa Virginia in relation to Brazil (Paglia et al. 2012), São Paulo State (Vivo et al. 2011) and NatureServe (2014) projections.

\begin{tabular}{|c|c|c|c|c|}
\hline Order & Brazil & São Paulo & $\begin{array}{l}\text { Projection of } \\
\text { NatureServe }\end{array}$ & Núcleo Santa Virginia \\
\hline Didelphimorphia & 55 & 24 & $19-22$ & $9^{(\mathrm{a})}$ \\
\hline Cingulata & 11 & 5 & $5-6$ & 3 \\
\hline Pilosa & 8 & 3 & 3 & 2 \\
\hline Primates & 118 & 10 & $5-8$ & $5^{(\mathrm{b})}$ \\
\hline Lagomorpha & 1 & 1 & 1 & 1 \\
\hline Carnivora & 26 & 17 & $12-15$ & $14^{(\mathrm{c})}$ \\
\hline Perissodactyla & 1 & 1 & 1 & 1 \\
\hline Artiodactyla & 10 & 8 & 6 & 3 \\
\hline Rodentia & 234 & 58 & $33-42$ & 20 \\
\hline TOTAL & 464 & 127 & $85-104$ & 58 \\
\hline
\end{tabular}

(a) One species with unconfirmed record; ${ }^{(b)}$ Two species with unconfirmed records; ${ }^{(c)}$ Three species with unconfirmed records.

identified by their conspicuous traits, is also a specialist animal for a particular type of habitat (streams, usually isolated) (Bianconi \& Rossi 2011), which is frequent in the area.

Both species of small mammals (Monodelphis americana and Akodon cursor) recorded exclusively during the elaboration of the Management Plan (Instituto Florestal 2006) deserve caution. Besides having cryptic characteristics, these taxa were not identified with cytogenetic or molecular analyzes during the technical work (A.P. Carmignotto pers. com.). All specimens of the genus Akodon and Monodelphis (with three stripes) collected during this study were genetically identified as $A$. montensis and Monodelphis iheringi respectively (R.D. Cardoso pers. com.). Thus, more detailed examination of the specimens collected on the Management Plan would be prudent to elucidate whether these species occur in sympatry in NSV.

As noted in the Management Plan, a single deer species represented the order Artiodactyla: Mazama americana. This result may be related to the low population density of cogeneras - especially M. gouazoubira, which is considered to be the most abundant and widely distributed Brazilian deer species (Duarte 1996) - or even the absence of individuals in the region. For the other orders of non-flying mammals, the richness observed in NSV was very close to the expected (Instituto Florestal 2006, NatureServe 2014).

The use of several complementary sampling methods was essential to provide a complete as possible list of mammals occurring in the NSV. For small mammals, the observed richness was satisfactory, accounting for $87 \%$ of the estimated species (Jackknife 1), of which 90\% were registered in the first half of the sampling effort (Figure 2). However, based on the collectors curve and the state and regional lists (Vivo et al. 2011, NatureServe 2014), new taxa should be incorporated, especially through the effort increment and sampling in other environments, such as different successional stages and altitudes.

Based on the elevated mammal richness, including many endangered species (Table 2) and with the presence of species from various trophic levels (e.g., herbivores, frugivores, carnivores, prey and predators), the uniqueness and significance of NSV for the maintenance and conservation of regional biodiversity becomes explicit. Also noteworthy is its relevance as a location for diverse ecological studies as well as studies that continue to inventory the local mammals, with an expansion of sampling methods and inclusion of the order Chiroptera.

\section{Acknowledgements}

This work was funded by the Fundação de Amparo à Pesquisa do Estado de São Paulo (FAPESP), through the processes 2001/14463-5 and 2007/03392-6 (Biota Program), 2001/10545-3 (RMM), 2007/00613-1 (FRM), and by CNPq $(\mathrm{CLN})$ and a productivity grant (MG). Support came from Ideal Wild, Conservation International, Project Gatos do Mato Brazil and the Onça-Pintada Institute. We thank Núcleo Santa Virgínia, Department of Ecology, Universidade Estadual Paulista (UNESP), Rio Claro excluir, for logistical support. Thanks to Camilla Bruno Di Nizo, Juliana Gualda-Barros, Dr. Julio Fernando Vilela, Dra. Lena Geise, Dra. Maria José de Jesus Silva and Rafaela Duda Cardoso for help in identifying small mammal species, Dr. Arthur Ângelo Bispo for providing the map, and João Paulo Villani and the other staff at NSV for their support, permission to work and information provided.

\section{References}

ABREU JR.E.F. \& KÖHLER, A.. 2009. Mastofauna de médio e grande porte na RPPN da UNISC, RS, Brasil. Biota Neotrop. 9(4):169-174, http://dx.doi.org/10.1590/S1676-06032009000400017

BARROS-BATTESTI, D.M., MARTINS, R., BERTIM, C.R., TOSHINARI, N.H., BONOLDI, V.L.N., LEON, E.P., MIRETZKI, M. \& SCHUMAKER, T.T.S. 2000. Land fauna composition of small mammals of a fragment of Atlantic Forest in the State of São Paulo, Brazil. Rev. Bras. Zool. 17(1):241-249, http://dx.doi.org/10.1590/S0101-81752000000100021

BIANCONI, G.V., MIKICH, S.B. \& PEDRO, W.A. 2004. Diversidade de morcegos (Mammalia, Chiroptera) em remanescentes florestais do município de Fênix, noroeste do Paraná, Brasil. Rev. Bras. Zool. 21(4):943-954, http://dx.doi.org/10.1590/S0101-81752004000400032

BRESSIANI, V.B., GRAIPEL, M.E. 2008. Comparação de métodos para captura da cuíca-d'água, Chironectes minimus (Zimmerman, 1780) (Mammalia, Didelphidae) no sul do Brasil. Mast.Neotrop. 15(1):33-39.

BROCARDO, C.R., RODARTE, R., BUENO, R.S., CULOT, L. \& GALETTI, M. Non-volant mammals of Carlos Botelho State Park, Paranapiacaba Forest Continuum. Biota Neotrop. 12(4): http://www.biotaneotropica.org. br/v12n4/pt/abstract?inventor$\mathrm{y}+\mathrm{bn} 02512042012$

CHEIDA, C.C., NAKANO-OLIVEIRA, E., FUSCO-COSTA, R., ROCHA-MENDES, F. \& QUADROS, J. 2011. Ordem Carnivora. In Mamíferos do Brasil (Reis, N.R., Peracchi, A.L., Pedro, W.A., \& Lima, I.P., eds.). Editora da UEL, Londrina, p.235-288.

CHIARELLO, A.G., AGUIAR, L.M.S., CERQUEIRA, R., MELO, F.R., RODRIGUES, F.H.G. \& SILVA, V.M. 2008. Mamíferos 
ameaçados de extinção no Brasil. In: Angelo Machado, B.M. Gláucia Drommond M. Adriano Paglia P. (Org.). Livro Vermelho da Fauna Brasileira Ameaçada de Extinção 1 ed. Belo Horizonte, MG: Ministério do Meio Ambiente e Fundação Biodiversitas, 2:681-702.

COLWELL, R.K. 2009. EstimateS 8.2.0. - Statistical Estimation of Species Richness and Shared species from Samples. http://viceroy. eeb.uconn.edu/EstimateS

CULLEN JR., L, BODMER, E \& PÁDUA, C.V. 2000. Effects of hunting in habitat fragments of the Atlantic forests, Brazil. Biol. Conserv. 95(1):49-56, http://dx.doi.org/10.1016/S0006-3207(00)00011-2

CUNHA, A.A \& RAJÃO, H. 2007. Mamíferos terrestres e aves da Terra Indígena Sapukai (Aldeia Guarani do Bracui), Angra dos Reis, RJ, Brasil. Bol. Mus. Biol. Mello Leitão (N. Sér.) 21:19-34.

DE VI.V.O., M \& GREGORIN, R. 2001. Mamíferos. In Intervales (Leonel, C., Ed.). São Paulo, p.117-122.

De VIVO, M., CARMIGNOTTO, A.P., GREGORIN, R., HINGSTZAHER, E., IACK-XIMENES, G.E., MIRETZKI, M., PERCEQUillo, A.R., ROLLO, M.M., ROSSI, R.V. \& TADDEI, V.A. Checklist dos mamíferos do Estado de São Paulo, Brasil. Biota Neotrop. 11(1a): http://www.biotaneotropica. org.br/v11n1a/pt/abstract?inventory+bn0071101a2011

DEAN, W. 1996. A ferro e fogo: a história e a devastação da Mata Atlântica brasileira. Companhia das Letras, São Paulo.

DI-NIZO, C.B., NEVES, C.L., VILELA, J.F. \& SILVA, M.J.J. 2014. New karyologycal data and cytotaxonomic considerations on small mammals from Santa Virgínia (Parque Estadual da Serra do Mar, Atlantic Forest, Brazil). Comparative Cytogenetics 8(1):11-30, http://dx.doi.org/10.3897/compcytogen.v8i1.6430

DUARTE, J.M.B. 1996. Guia de identificação de cervídeos brasileiros. $1^{\mathrm{a}}$.ed. FUNEP.

EISENBERG, J.F. \& REDFORD, K.H. 1999. Mammals of the neotropics (Volume 3) The Central Neotropics: Ecuador, Peru, Bolivia, Brazil. The University of Chicago Press, Chicago, London.

EMMONS, L.H. \& FEER, F. 1997. Neotropical rainforest mammals: a field guide. The University of Chicago Press, Chicago.

FARIA, D., SOARES-SANTOS, B. \& SAMPAIO, E. 2006. Bats from the Atlantic rainforest of southern Bahia, Brazil. Biota Neotrop. 6(2):1-13, http://dx.doi.org/10.1590/S1676-06032006000200022

FAUNA AMEAÇADA DE EXTINÇÃO NO ESTADO DE SÃO PAULO. VERTEBRADOS 2009. Coordenação geral: Bressan, P.M., Maria Cecília Martins Kierulff, M.C.M. Sugieda, A.M. São Paulo: Fundação Parque Zoológico de São Paulo: Secretaria do Meio Ambiente.

GALETTI, M. \& CHIVERS, D.J. 1995. Palm harvest threatens Brazil's best protected area of Atlantic Forest. Oryx 29:225-226.

GALETTI, M. \& FERNANDEZ, J.C. 1998. Palm Heart Harvesting in the Brazilian Atlantic Forest: Changes in Industry Structure and the Illegal Trade. Journal of Applied Ecology 35(2):294-301, http:// dx.doi.org/10.1046/j.1365-2664.1998.00295.x

GALETTI, M., GIACOMINI, H.C., BUENO, R.S., BERNARDO, C.S.S., MARQUES, R.M., BOVENDORP, R.S., STEFFLER, C.E., RUBIM, P., GOBBO, S.K., DONATTI, C.I., BEGOTTI, R.A., MEIRELlES, F., NOBRE, R.A., CHIARELlO, A.G. \& PERES, C.A. 2009. Priority areas for the conservation of Atlantic forest large mammals. Biol. Conserv. 142:1229-1241, http:// dx.doi.org/10.1016/j.biocon.2009.01.023

GEISE, L., PEREIRA, L.G., BOSSI, D.E.P. \& BERGALlO, H.G. 2004. Pattern of elevational distribution and richness of non volant mammals in Itatiaia National Park and its surrounding, in the southeastern Brazil. Rev. Bras. Biol. 64(3B):599-612.

GOERCK, J.M. 1999. Distribuition of bird along na elevational gradient in the Atlantic forest of Brazil: implications for the conservation of the endemic and endangered species. Bird Conserv. Int. 9:235-253, http://dx.doi.org/10.1017/S0959270900003439

GOMIERO, L.M. \& BRAGA, F.M.S. 2006. Diversity of the ichthyofauna in the Serra do Mar State Park- Núcleo Santa Virgínia, São Paulo State, Brazil. Acta Sci. Biol. Sci. 28(3):213-218.
HARTMANN, P.A., HARTMANN, M.T. \& MARTINS, M. 2009. Ecologia e história natural de uma taxocenose de serpentes no Núcleo Santa Virgínia do Parque Estadual da Serra do Mar, no sudeste do Brasil. Biota Neotrop. 9(3):173-184, http://dx.doi.org/ 10.1590/S1676-06032009000300018

INSTITUTO FLORESTAL. 2006. Plano de Manejo do Parque Estadual da Serra do Mar. São Paulo.

IUCN - International Union for Conservation of Nature and Natural Resources. 2001.IUCN Red List Categories and Criteria: Version 3.1. IUCN Species Survival Comission. IUCN, Gland, Switzerland and Cambridge, UK. ii +30 pp.

LUZ, J.L., COSTA, L.M., LOURENÇO, E.C. \& ESBERARD, C.E.L. Morcegos (Mammalia, Chiroptera) da Reserva Rio das Pedras, Rio de Janeiro, Sudeste do Brasil. Biota Neotrop. 11(1) http://www. biotaneotropica.org.br/v11n1/pt/abstract?article+bn01711012011 ISSN 1676-0603.

MACHADO, A.B.M., MARTINS, C.S. \& DRUMOND, G.M. 2005. Lista vermelha da fauna ameaçada de extinção. Fundação Biodiversitas, Belo Horizonte.

MARQUES, R.M. 2004. Diagnóstico das populações de aves e mamíferos cinegéticos do Parque Estadual da Serra do Mar, SP, Brasil. Dissertação de mestrado, Universidade de São Paulo, Piracicaba.

MARTINS, N. 2011. Número mínimo de indivíduos e diversidade genética de onça-parda (Puma concolor) no Núcleo Santa Virgínia, Parque Estadual da Serra do Mar, São Paulo. Dissertação de Mestrado, Universidade Federal de São Carlos, São Carlos.

MMA. Ministério do Meio Ambiente. 2002. Biodiversidade Brasileira. Brasília.

MMA Fundação Biodiversitas. 2008. Livro vermelho da fauna brasileira ameaçada de extinção. $1^{\mathrm{a}}$ ed. 2 v. Machado, G.M.D. Paglia, A.P. (Eds.) Brasília, DF, Belo Horizonte, MG.1420p.

MODESTO, T.C., PESSOA, F.S., ENRICI, M.C.. ATTIAS, N., JORDû O-NOGUEIRA, T.. COSTA, L.M., ALBUQUERQUE, H.G. \& BERGALLO, H.G. 2008. Mamíferos do Parque Estadual do Desengano, Rio de Janeiro, Brasil. Biota Neotrop. 8(4):153-159, http://dx.doi.org/10.1590/S1676-06032008000400015

NATURASERVE.2014. http://www.natureserve.org/infonatura/ maps_groups_not_limited/Lmap_mammals_groups_not_limited. htm.en. (last access 21/07/2014)

NEGRÃO, M.F.F. \& VALLADARES-PÁDUA, C. 2006. Registros de mamíferos de maior porte na Reserva Florestal do Morro Grande, São Paulo. Biota Neotrop. 6(2):1-13, http://dx.doi.org/10.1590/S167606032006000200006

PAGLIA, A.P., LOPES, M.O.G., PERINI, F.A. \& CUNHA, H.M. 2005. Mammals of the Estação de Preservação e Desenvolvimento Ambiental de Peti (EPDA-Peti), São Gonçalo do Rio Abaixo, Minas Gerais, Brazil Lundiana 6(supplement):89-96.

PAGLIA, A.P., FONSECA, G.A.B DA, RYLANDS, A.B., HERRMANN, G., AGUIAR, L.M.S., CHIARELlO, A.G., LEITE, Y.L.R., COSTA, L.P., SICILIANO, S., KIERULFF, M.C.M., MENDES, S.L., TAVARES, V.C., MITTERMEIER, R.A. \& PATTON J L. 2012. Lista Anotada dos Mamíferos do Brasil / Annotated Checklist of Brazilian Mammals. 2 ${ }^{\mathrm{a}}$ Edição / 2nd Edition. Occasional Papers in Conservation Biology, No. 6. Conservation International, Arlington, VA. 76pp.

PARDINI, R. \& UMETSU, F. 2006. Pequenos mamíferos não-voadores da Reserva Florestal do Morro Grande - distribuição das espécies e da diversidade em uma área de Mata Atlântica. Biota Neotrop. 6(2):1-22, http://dx.doi.org/10.1590/S1676-06032006000200007

PASSAMANI, M., DALMASCHIO, J. \& LOPES, S.A. 2005. Mamíferos não-voadores em áreas com predomínio de Mata Atlântica da Samarco Mineração S.A., município de Anchieta, Espírito Santo. Biotemas 18(1):135-149.

PINHEIRO, P.S. \& GEISE, L. 2008. Non-volant mammals of Picinguaba, Ubatuba, state of São Paulo, southeastern Brazil. Bol. Mus. Biol. Mello Leitão. 23:51-59.

PINTO, I.S., LOSS, A.C.C., FALQUETO, A. \& LEITE, Y.L.R. 2009. Non-flying small mammals in Atlantic Forest fragments and agricul- 
tural lands in Viana, state of Espírito Santo, Brazil. Biota Neotrop. 9(3):355-360, http://dx.doi.org/10.1590/S1676-06032009000300030

PINTO, L.P., BEDÊ, L., PAESE, A., FONSECA, M., PAGILIA, A. \& LAMAS, I., 2006. Mata Atlântica brasileira: os desafios para a conservação da biodiversidade de um hotspot mundial. In Biologia da Conservação: Essências (Rocha, C.F.D., Bergallo, H.G., Sluys, M.V. \& Alves, M.A.S., eds.). RiMa, São Carlos, p.91-118.

RIBEIRO, M.C., METZGER, J.P., MARTENSEN A.C., PONZONI F.J. \& HIROTA, M.M. 2009. The Brazilian Atlantic Forest: How much is left, and how is the remaining forest distributed? Implications for conservation. Biol. Conserv. 142:1141-1153, http://dx.doi.org/10.1016/j.biocon.2009.02.021

ROCHA-MENDES, F. 2010. Efeitos da defaunação na herbivoria, pisoteio de plântulas, remoção e predação de sementes na floresta Atlântica. 2010. Tese de Doutorado, Universidade Estadual Paulista Júlio de Mesquita Filho, UNESP Rio Claro, Rio Claro.

ROSSI, R.V. \& BIANCONI, G.V. 2011. Ordem Didelphimorphia. In Mamíferos do Brasil (Reis, N.R., Peracchi, A.L., Pedro, W.A. \& Lima, I.P., eds.). Editora da UEL, Londrina, p.31-69.

SIKES, R.S., GANNON, W.L. \& The Animal Care and Use Committee of the American Society of Mammalogists. 2011.
Guidelines of the American Society of Mammalogists for the use of wild mammals in research. J. Mammal. 92:235-253, http:// dx.doi.org/10.1644/10-MAMM-F-355.1

SILVA, E.D. \& TOZZI, A.M.G.A. 2013. Leguminosae na Floresta Ombrófila Densa do Núcleo Santa Virgínia, Parque Estadual da Serra do Mar, São Paulo, Brasil. Rodriguésia 64(2): 285309.

SMA. Secretaria de Estado do Meio Ambiente. 1999. Paisagem paulista: áreas protegidas. Empresa das Artes, São Paulo.

SOS Mata Atlântica. 2010. http://mapas.sosma.org.br/ (last access 05/ 12/2011)

TABARELLI, M., VILLANI, J.P. \& MANTOVANNI W. 1994. Estudo comparativo da vegetação de dois trechos de floresta secundária no Núcleo Santa Virgínia/SP. Rev. Inst. Florest. 6(1):1-11.

VOSS, R.S. \& EMMONS, L.H. 1996. Mammalian Diversity in Neotropical Lowland Rainforests: A Preliminary Assessment. Bull. Am. Mus. Nat. Hist 230.

WANG E. 2002. Diets of Ocelots (Leopardus pardalis), Margays ( $L$. wiedii), and Oncillas (L.tigrinus) in the Atlantic rainforest in southeast Brazil. Studies on Neotropical Fauna and Environment, 37(3):207-212, http://dx.doi.org/10.1076/snfe.37.3.207.8564 